\title{
Dental status, dental rehabilitation procedures, demographic and oncological data as potential risk factors for infected osteoradionecrosis of the lower jaw after radiotherapy for oral neoplasms: a retrospective evaluation
}

\author{
Marcus Niewald ${ }^{1 *}$, Jochen Fleckenstein ${ }^{1}$, Kristina Mang ${ }^{2}$, Henrik Holtmann ${ }^{3}$, Wolfgang J Spitzer ${ }^{3}$ \\ and Christian Rübe ${ }^{1}$
}

\begin{abstract}
Purpose: Retrospective evaluation of the dental status of patients with oral cancer before radiotherapy, the extent of dental rehabilitation procedures, demographic and radiotherapy data as potential risk factors for development of infected osteoradionecrosis of the lower jaw.

Methods: A total of 90 patients who had undergone radiotherapy for oral cancer were included into this retrospective evaluation. None of them had distant metastases. After tumour surgery the patients were referred to an oral and maxillofacial surgeon for dental examination and the necessary dental rehabilitation procedures inclusive potential tooth extraction combined with primary soft tissue closure. Adjuvant radiotherapy was started after complete healing of the gingiva ( $>7$ days after potential extraction). The majority of patients $(n=74)$ was treated with conventionally fractionated radiotherapy with total doses ranging from 50-70Gy whereas further 16 patients received hyperfractionated radiotherapy up to 72Gy. The records of the clinical data were reviewed. Furthermore, questionnaires were mailed to the patients' general practitioners and dentists in order to get more data concerning tumour status and osteoradionecrosis during follow-up.
\end{abstract}

Results: The patients' dental status before radiotherapy was generally poor. On average 10 teeth were present, six of them were regarded to remain conservable. Extensive dental rehabilitation procedures included a mean of 3.7 tooth extractions. Chronic periodontitis with severe attachment loss was found in 40\%, dental biofilm in 56\%. An infected osteoradionecrosis (IORN) grade II according to (Schwartz et al., Am J Clin Oncol 25:168-171, 2002) was diagnosed in 11 of the 90 patients (12\%), mostly within the first 4 years after radiotherapy. We could not find significant prognostic factors for the occurrence of IORN, but a trendwise correlation with impaired dental status, rehabilitation procedures, fraction size and tumour outcome.

Conclusion: The occurrence of IORN is an important long-term side effect of radiotherapy for oral cancers. From this data we only can conclude that a poor dental status, conventional fractionation and local tumour progression may enhance the risk of IORN which is in concordance with the literature.

Keywords: Dental status, Dental rehabilitation procedures, Radiotherapy, Fractionation, Infected osteoradionecrosis

\footnotetext{
* Correspondence: marcus.niewald@uks.eu

'Department of Radiotherapy and Radiooncology, Saarland University

Medical Center, Kirrberger Str. 1, D-66421 Homburg, Germany

Full list of author information is available at the end of the article
} 


\section{Background}

The dental status of patients with neoplasms of the head and neck region is known to be more unfavourable compared to healthy persons. Some reasons may be the frequent abuse of nicotine and alcohol and limited dental hygiene. These factors may increase the risk for developing infected osteoradionecrosis (IORN) after radiotherapy as a typical long-term side effect [1]. To our knowledge, IORN can only be sufficiently avoided performing by extensive dental rehabilitation procedures including extraction of teeth. Nevertheless, IORN occurs in a frequency ranging from $0-22 \%$ [2]. Because of the necrosis of the gingiva, erosion and sequestration of the jaw bone and dentoalveolar abscess formation sufficient chewing and thus nutrition of the patient can be problematic and thus impair the quality of life of those patients by a large extent.

16 years ago we have published a retrospective evaluation of the frequency and risk factors for IORN [2]. The frequency of IORN in patients after conventionally fractionated radiotherapy (total dose 60-70Gy) was 8.6\% while the same rate amounted to $22.9 \%$ in patients with hyperfractionated radiotherapy (total dose 82.8Gy). We concluded that this excessive occurrence of IORN in patients having been treated with a hyperfractionated irradiation regimen was probably caused by the high total dose and a too short interfraction interval.

In the presented analysis, we performed a second evaluation of frequency and risk factors for IORN in a totally different collective of patients having undergone radiotherapy in the years 1993-2001.

\section{Methods}

Ninety patients with histologically proven squamous-cell cancers of the oral cavity treated in the years 1993-2001 were included into this retrospective evaluation. The majority had primary tumors, one a local recurrence but had not been irradiated before, none had distant metastases. The mean age at the beginning of radiotherapy was 57 years, the mean Karnofsky performance index 7.8. Sixty-four patients had undergone prior surgery, the remaining 24 had not.

Dental examination and treatment procedures were performed as early as possible with a minimal time interval of 7-10 days from the last procedure to the beginning of radiotherapy. All dental extractions were performed according to a written protocol under "special care" (primary tissue closure, perioperative antibiotics for 7-10 days beginning one day before surgery). In the nineties all patients were advised not to wear their dental prostheses up to 6-12 months after radiotherapy (today after complete healing of mucositis) $[3,4]$.

After completion of all dental examination and rehabilitation procedures (Tab. 3), all patients underwent radiotherapy. 74 patients were treated in a conventionally
Table 1 Patients' demographical and oncological data $(\mathrm{n}=90)$

\begin{tabular}{lcccc}
\hline Item & Mean value & $\begin{array}{c}\text { Minimum } \\
\text { value }\end{array}$ & $\begin{array}{c}\text { Maximum } \\
\text { value }\end{array}$ & Remarks \\
\hline Age & 56.97 & 21.1 & 84.0 & Years \\
$\begin{array}{l}\text { Karnofsky } \\
\text { performance } \\
\text { status }\end{array}$ & $78 \%$ & $50 \%$ & $100 \%$ & \\
Follow-up & & & & \\
\hline
\end{tabular}

\begin{tabular}{cc}
\hline Item & Value (\%) \\
\hline T-stage & \\
T1 & $14(16 \%)$ \\
T2 & $33(37 \%)$ \\
T3 & $8(9 \%)$ \\
T4 & $35(38 \%)$
\end{tabular}

N-stage

$\begin{array}{cc}\text { N0 } & 20(22 \%) \\ \text { N1 } & 24(27 \%) \\ \text { N2 } & 46(51 \%) \\ \text { N3 } & 0\end{array}$

UICC stage

$\begin{array}{cc}\text { I } & 7(8 \%) \\ \text { II } & 6(7 \%) \\ \text { III } & 11(12 \%) \\ \text { IV } & 66(73 \%)\end{array}$

Pre-treatment

None $\quad 27(30 \%)$

Surgery $\quad 61(70 \%)$

Surgery to the lower jaw

Partial resection $16(23 \%)$

Continuity resection $10(14 \%)$

Chemotherapy $17(19 \%)$

Radiotherapy - fractionation

$\begin{array}{lc}\text { Conventional } & 74(82 \%) \\ \text { Hyperfractionation } & 16(18 \%) \\ \text { Fraction size } & \\ 1 \times 2.0 & 72(80 \%) \\ 1 \times 3.0 & 2(2 \%) \\ 2 \times 1.2 & 15(17 \%) \\ 2 \times 1.4 & 1(1 \%)\end{array}$

total dose - conventionally fractionated $(n=75)$
Gy

Gy/day

1 (1\%)

1 (1\%)

7 (9\%)

$2(2 \%)$

31 (44\%)

9 (13\%)

23 (31\%) 
Table 1 Patients' demographical and oncological data ( $\mathbf{n}=\mathbf{9 0}$ ) (Continued)

\begin{tabular}{cc}
\hline Total dose - hyperfractionated $(\mathrm{n}=15)$ \\
58.8 & $1(6 \%)$ \\
70.8 & $1(6 \%)$ \\
72.0 & $12(76 \%)$ \\
72.8 & $1(6 \%)$ \\
76.8 & $1(6 \%)$ \\
\hline
\end{tabular}

fractionated manner applying total doses of 60Gy $(n=33)$ up to 70Gy $(\mathrm{n}=23)$. Ten patients received 64Gy mainly due to compensation for holidays and accelerator breakdowns while the remaining 10 patients got 36-58Gy mostly due to deterioration of the general health status during radiotherapy or the withdrawal of informed consent by the patient. Sixteen patients were treated in a hyperfractionated manner with two daily single doses of $1.2 \mathrm{~Gy}$ with an interfraction interval of more than 6 hours thus reaching a total dose of $72 \mathrm{~Gy}(\mathrm{n}=11)$. The remaining four patients had total doses ranging from 58.8 to $76.8 \mathrm{~Gy}$ due to the same reasons as stated above. Total doses were defined to the ICRU (International Commission on Radiation Units) 50 reference point. Volume data were available only for the last few patients so that these are considered here. The dose distributions were reviewed, the mandible was well within the $100 \%$ isodose.

After production of a fixation mask and the planning procedure based on a computerized tomography of the head and neck region, radiotherapy regularly was performed by laterolateral parallel opposing irregular portals formed by beam blocks or by a multileaf collimator using 4-6 MV photons of a linear accelerator. After a total dose ranging from 30-50Gy the spinal cord was spared by a dorsal field reduction. The resulting underdosage of the level $\mathrm{V}$ region was supplemented by applying lateral opposing electron portals there up to the primarily intended total dose.

In 17 patients not having been operated on before chemotherapy consisting of cis-platinum and 5-fluorouracil was applied simultaneously. Further demographical and oncological details are depicted in Table 1.

During radiotherapy, the patients received oral care by the dental colleagues (inhouse). Fluoridation was performed according to dental advice. Splints were not used normally due to the experience that the majority of patients used them incorrectly and thus enhanced oral mucositis.

After radiotherapy, dental follow-up was performed by their local dentists. Consequently, detailed data about this phase are not available. Patients with IORN were referred to the Dept. of Oral and Maxillofacial Surgery for further treatment.
Table 2 Dental status before starting radiotherapy

\begin{tabular}{|c|c|c|c|c|}
\hline Teeth $(n=)$ & Mean value & $\begin{array}{l}\text { Minimum } \\
\text { value }\end{array}$ & $\begin{array}{c}\text { Maximum } \\
\text { value }\end{array}$ & $\begin{array}{l}\text { Data available } \\
\text { from } n \text { patients }\end{array}$ \\
\hline Absent & 22.0 & 0 & 32 & 89 \\
\hline Present & 10.1 & 0 & 32 & 89 \\
\hline Carious & 2.0 & 0 & 21 & 85 \\
\hline Destroyed & 1.4 & 0 & 21 & 87 \\
\hline Loose & 1.6 & 0 & 13 & 84 \\
\hline Root remainders & 0.3 & 0 & 5 & 87 \\
\hline Devital & 0.5 & 0 & 4 & 86 \\
\hline $\begin{array}{l}\text { Roots - filled } \\
\text { completely }\end{array}$ & 0.2 & 0 & 2 & 84 \\
\hline $\begin{array}{l}\text { Roots - filled } \\
\text { incompletely }\end{array}$ & 0.3 & 0 & 4 & 85 \\
\hline $\begin{array}{l}\text { Apical } \\
\text { periodontitis }\end{array}$ & 0.3 & 0 & 4 & 86 \\
\hline Cysts & 0.2 & 0 & 3 & 85 \\
\hline Retained & 0.2 & 0 & 2 & 84 \\
\hline $\begin{array}{l}\text { Conservative } \\
\text { treatment possible }\end{array}$ & 5.8 & 0 & 30 & 88 \\
\hline $\begin{array}{l}\text { No conservative } \\
\text { treatment possible }\end{array}$ & 4.3 & 0 & 25 & 88 \\
\hline Filled & 2.3 & 0 & 20 & 82 \\
\hline $\begin{array}{l}\text { Not sufficiently } \\
\text { filled teeth }\end{array}$ & 0.8 & 0 & 11 & 82 \\
\hline $\begin{array}{l}\text { Teeth with not } \\
\text { sufficient crowns }\end{array}$ & 0.2 & 0 & 2 & 82 \\
\hline Item & $\begin{array}{l}\text { Number of } \\
\text { patients (\%) }\end{array}$ & & & $\mathrm{n}=$ \\
\hline
\end{tabular}

Chronic periodontitis with less to moderate attachment loss

$\begin{array}{ll}\text { Localized } & 7(8 \%) \\ \text { General } & 9(11 \%)\end{array}$

Chronic periodontitis with severe attachment loss

$\begin{array}{ll}\text { Localized } & 12(14 \%) \\ \text { General } & 35(40 \%)\end{array}$

Biofilm

None $\quad 1(2 \%)$

Moderate $21(42 \%)$

Intense $\quad 30(56 \%)$

Dental calculi and subgingival concrements 53

$\begin{array}{lc}\text { None } & 1(2 \%) \\ \text { Moderate } & 22(42 \%) \\ \text { Intense } & 30(56 \%) \\ \text { Dental hygiene } & \\ \text { Good } & 3(6 \%) \\ \text { Poor } & 21(39 \%) \\ \text { Not sufficient } & 30(55 \%)\end{array}$

All patients' records were reviewed. The dental status and the extent of dental rehabilitation procedures were extracted from the files in the Department of Oral 
Table 3 Dental treatment procedures

\begin{tabular}{|c|c|c|c|c|}
\hline Teeth $(n=)$ & Mean value & Minimum value & Maximum value & Data available from $\mathrm{n}$ patients \\
\hline Endodontic treatment & 0.05 & 0 & 2 & 88 \\
\hline Removal of root remainders with primary tissue closure & 0.2 & 0 & 5 & 88 \\
\hline Tooth extraction with primary tissue closure & 3.7 & 0 & 22 & 89 \\
\hline Conserving treatment & 0.6 & 0 & 6 & 88 \\
\hline Cystectomy & 0.1 & 0 & 2 & 87 \\
\hline Healthy teeth remaining after dental rehabilitation & 6.2 & 0 & 30 & 89 \\
\hline Edentulous after dental treatment & 47 patients (52\%) & & & \\
\hline
\end{tabular}

and Maxillofacial Surgery. Furthermore, all x-rays (orthopantomograms) were re-examined. Infected osteoradionecrosis (IORN) was (at minimum) defined here as infected mucosal ulcers with eroded mandibular bone underneath (grade II according to Schwartz et al. [5]). The radiooncological data were extracted from the files in the Department of Radiotherapy and Radiooncology. Additionally, standardized questionnaires were mailed to the patients' medical doctors, dentists and local authorities three times within the observation period in order to achieve additional data concerning tumor outcome, occurrence of IORN and general health status.

All data were entered into a medical database (MEDLOG, Parox Comp., Münster, Germany). Distributions and means were computed. For survival curves and failure curves (occurrence of IORN) the Kaplan Meier estimate was used. These curves were compared using the Mantel Haensel test.

Prognostic parameters for IORN were analyzed univariately by comparison of means and distributions in a group containing the patients with IORN compared to another group with the patients who never experienced IORN using the t-test, u-test and chi-square test in the appropriate variables. Multivariate search for independent prognostic factors was performed by logistic regression.

All patients had given their written informed consent to surgery, dental rehabilitation procedures and radiotherapy before treatment. The approval by the local ethics committee was dispensable due to the retrospective evaluation performed here. This research is in concordance with the Declaration of Helsinki.

Table 4 Dental treatment after radiotherapy

\begin{tabular}{lc}
\hline Treatment & $\begin{array}{c}\text { Number of } \\
\text { patients (\%) }\end{array}$ \\
\hline None & $73(81 \%)$ \\
Conservative treatment & $2(2 \%)$ \\
Tooth extraction with primary tissue closure & $14(16 \%)$ \\
$\begin{array}{l}\text { Tooth extraction with primary tissue closure and } \\
\text { conservative treatment }\end{array}$ & $1(1 \%)$ \\
\hline
\end{tabular}

\section{Results}

\section{General remarks}

Up to July 2013, 58 patients were dead with a mean follow-up of 2.4 [0-8.8] years. The patients known to be alive were seen irregularly, the most recent information resulted from questionnaires, nearly all patients were lost to follow-up after on average $7.4[0-15]$ years.

\section{Dental findings before radiotherapy}

The patients' dental status was generally poor. On average, only 10 teeth were present (and thus 22 teeth missing) at the beginning of therapy in the oral cavity. Of those, on average 2.0 were carious, 1.5 loose (clinical grade II-III) and 1.4 deeply destroyed. As a result of the meticulous dental examination only a mean of six teeth was regarded to remain conservable on average. $11 \%$ of the patients showed chronic periodontitis with less to moderate attatchment loss while in $40 \%$ chronic periodontitis with severe attatchment loss was diagnosed.

Additionally, plaque was found frequently; $56 \%$ of the patients had dental biofilm and dental calculi and subgingival concrements, respectively. The general dental hygiene was classified separately by a dentist as poor in $55 \%$ of the patients. These findings are based on the data of 53 patients, further information was not available in the files. The detailed data are depicted in Table 2.

Data on the use of dental prostheses are available for $65 / 90$ patients. Partial prostheses were used by six patients in the upper jaw and by 22 patients in the lower jaw. Complete prostheses were used by 34 patients in the upper jaw and by 15 patients in the lower jaw. The patients had been counselled not to wear their prostheses during radiotherapy and 12 months afterwards.

\section{Dental rehabilitation procedures before and after radiotherapy}

All patients were referred to the dentist and oromaxillofacial surgeon for dental and surgical treatment, $89 / 90$ have been seen there. The dental rehabilitation procedures necessary before radiotherapy were very extensive: on average 3.7 teeth had to be extracted followed by primary soft tissue closure of the extraction alveoles. The 


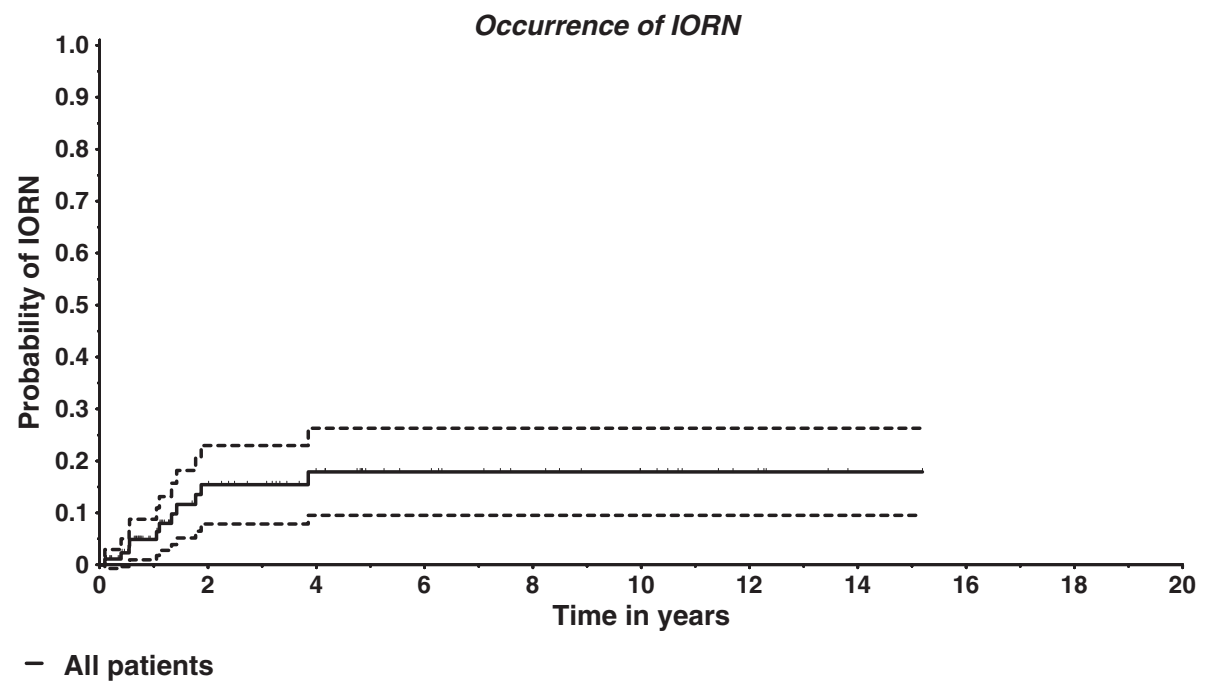

Figure 1 Occurrence of IORN over time (Kaplan-Meier estimate and 95\% confidence interval).

extraction was followed up by an interval of at least 710 days using soft diet, valid antibiosis and prosthodontic abstention. The detailed data to this point are summarized in Table 3.

During follow-up after radiotherapy additional dental treatment procedures were necessary in 17 patients the data are depicted in Table 4.

\section{Frequency, risk factors and therapy of infected osteoradionecrosis}

11 patients (12\%) were found to have developed infected osteoradionecrosis during follow-up. The one-year prevalence was $5 \%$, the two- and three-year prevalence $15 \%$.

All of them had been treated by conventionally fractionated radiotherapy applying doses of 50Gy (1 pat.), 60Gy (4 pats.), 64Gy (3 pats.), and 70Gy (3 pats.), respectively. Nine of these patients had undergone tumour resection, two had not. Additionally, two patients had undergone a partial resection of the lower jaw, further three patients a continuity resection of the lower jaw. In total, 9/64 patients (14\%) having been operated on had IORN compared to only $8 \%$ in the non-surgical patients.

In the group treated by hyperfractionation no patient with IORN could be identified. The Kaplan Meier estimate shows that IORN normally occurs within the first four years after radiotherapy, after that time new IORN cases were very rare (Figure 1).

All parameters mentioned in Tables 1, 2, 3 and 4 were tested univariately for potential prognostic significance for the occurrence of IORN. Results of this analysis are depicted in Table 5. The number of carious teeth and of odontogenic cysts in the lower jaw were found significant prognostic factors, for the numbers of present teeth before dental treatment and of remaining teeth after dental treatment a trend can be assumed. Multivariate analysis showed "odontogenic cysts" as the only significant factor.

The treatment of infected osteoradionecrosis consisted of non-continuously bone resection in two patients, surgery without bone resection in further three. Two patients were treated conservatively while one underwent hyperbaric oxygen therapy. The remaining three patients were not treated at all.

\section{Oncological results}

Due to the patients' very limited compliance the outcome data were incomplete. The following numbers show the frequency of recurrence or progression compared to the number of patients with sufficient data available.

A local tumor progression was found in 25/73 patients (34\%), a progression in the regional lymph nodes in $12 / 61$ patients $(20 \%)$, and distant metastases in $12 / 59$ patients (20\%). No sufficient data to this point were available from the remaining patients. The median survival time was 3.1 years. The two-year survival rate was $62 \%$ while the five-year survival rate amounted to $41 \%$. The Kaplan-Meier estimate for overall survival is depicted in Figure 2. As to acute side effects occurring during or shortly after radiotherapy, oral mucositis grade II WHO was found in 47 patients (54\%), grades III and IV in further 5 patients $(6 \%, n=87)$. Sialadenosis (dryness of mouth) as a typical long-term side effect of radiotherapy was found in 72 patients (82\%; grade 1 
Table 5 Prognostic factors for the occurrence of IORN in the lower jaw

\begin{tabular}{|c|c|c|}
\hline \multicolumn{3}{|l|}{ Univariate analysis } \\
\hline Teeth & $\mathrm{p}=$ & Remarks \\
\hline \multicolumn{3}{|l|}{ Dental status before starting radiotherapy } \\
\hline Absent & 0.093 & \\
\hline Present & 0.095 & Trend \\
\hline Carious & 0.047 & Significant \\
\hline Destroyed & 0.556 & \\
\hline Loose & 0.730 & \\
\hline Root remainders & 0.247 & \\
\hline Devital & 0.688 & \\
\hline Roots - filled completely & 0.555 & \\
\hline Roots - filled incompletely & 0.774 & \\
\hline Apical periodontitis & 0.956 & \\
\hline Cysts & 0.023 & Significant \\
\hline Retained & 0.291 & \\
\hline Conservative treatment possible & 0.129 & \\
\hline No conservative treatment possible & 0.830 & \\
\hline Filled & 0.758 & \\
\hline Not sufficiently filled teeth & 0.517 & \\
\hline Teeth with not sufficient crowns & 0.897 & \\
\hline \multicolumn{3}{|l|}{ Item } \\
\hline $\begin{array}{l}\text { Chronic periodontitis with less to moderate } \\
\text { attatchment loss }\end{array}$ & 0.572 & \\
\hline \multicolumn{3}{|l|}{ Localized } \\
\hline \multicolumn{3}{|l|}{ General } \\
\hline Chronic periodontitis with severe attatchment loss & 0.548 & \\
\hline \multicolumn{3}{|l|}{ Localized } \\
\hline \multicolumn{3}{|l|}{ General } \\
\hline Biofilm & 0.188 & \\
\hline \multicolumn{3}{|l|}{ None } \\
\hline \multicolumn{3}{|l|}{ Moderate } \\
\hline \multicolumn{3}{|l|}{ Intense } \\
\hline Dental calculus and subgingival concrements & 0.188 & \\
\hline \multicolumn{3}{|l|}{ None } \\
\hline \multicolumn{3}{|l|}{ Moderate } \\
\hline \multicolumn{3}{|l|}{ Intense } \\
\hline Partial prosthesis in lower jaw & 0.5254 & \\
\hline Complete prosthesis in lower jaw & 0.9026 & \\
\hline \multicolumn{3}{|l|}{ Dental treatment before radiotherapy } \\
\hline Endodontic treatment & 0.474 & \\
\hline Removal of root remainders & 0.413 & \\
\hline Tooth extraction & 0.939 & \\
\hline Conserving treatment & 0.498 & \\
\hline Cystectomy & 0.261 & \\
\hline
\end{tabular}

Table 5 Prognostic factors for the occurrence of IORN in the lower jaw (Continued)

\begin{tabular}{lll}
\hline Healthy teeth remaining after dental rehabilitation & 0.085 & Trend \\
Dental treatment after radiotherapy & 0.768 & \\
Demographic and oncological data & \\
Age & 0.118 \\
Karnofsky performance status & 0.455 \\
T-stage & 0.784 \\
N-stage & 0.797 \\
Total dose & 0.774 \\
BED2 & 0.410 \\
Daily fraction & 0.170 \\
\hline Multivariate analysis & \\
\hline Carious teeth & 0.1808 \\
Present teeth & 0.3154 \\
Odontogenic cysts & 0.0180 Significant \\
Healthy teeth remaining after dental treatment & 0.1552 \\
\hline
\end{tabular}

EORTC/RTOG: 22 patients (25\%), grade 2: 38 patients $(43 \%)$, grade 3: 12 patients $(14 \%) ; n=88)$.

\section{Discussion}

The authors are well aware of the limitations of this retrospective evaluation. In this nearly homogenous collective of patients with oral cavity cancer having undergone radiotherapy $+/-$ surgery, we have found complete data sets concerning dental status and restoration procedures of nearly all patients. The IORN data have been investigated meticulously, but due to the known incompliance of head and neck patients we cannot exclude that single events did not become known to the authors.

\section{Dental health status}

The comparison of our data concerning dental findings before radiotherapy to those of the Forth German Trial of Oral Health (original name in German: IV. Deutsche Mundgesundheitsstudie des Instituts der Deutschen Zahnärzte DMS IV) resulted in notable differences [6]. Summarizing the data of more than 4000 Germans before dental treatment, in adults (33-44 years of age) on average 14.5 teeth were found carious, in older people ( $>=45$ years of age) 22.1 teeth. These teeth were rehabilitated completely in $95.6 \%$ and in $94.8 \%$, respectively. A mean of 2.77 teeth in adults and of 14.2 teeth in older people were missing. $72 \%$ of the adults and $60.6 \%$ of the seniors were found to perform sufficient mouth hygiene. All these values were improved compared to the results of a former trial in 1997. On the other hand, the frequency of periodontitis was rising (moderate in $52.9 \%$ and intense in $39.8 \%$ of the population). Compared to those data our findings in patients with 


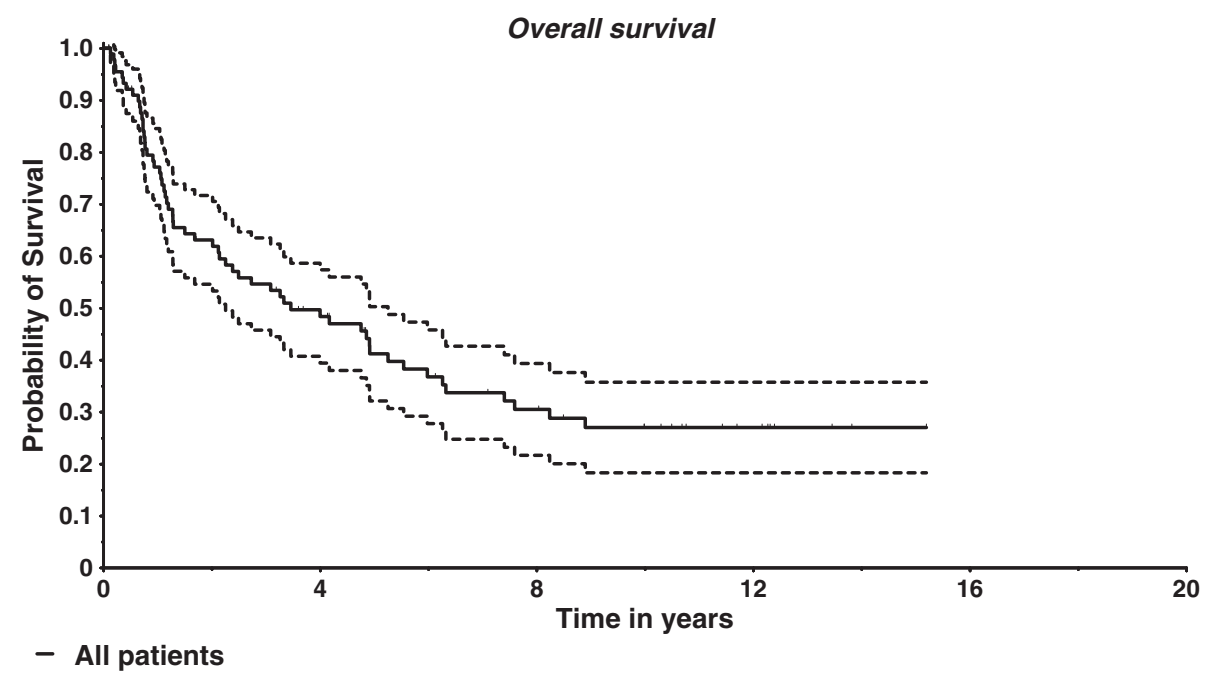

Figure 2 Overall survival (Kaplan-Meier estimate and 95\% confidence interval).

oral neoplasms are much more unfavourable. Further equally detailed analyses are rare. Jham et al. reported 2008 a collective of 207 patients with head and neck cancer with similar dental findings detecting periodontal disease in $41 \%$, retained roots in $21 \%$, carious teeth in $12 \%$, and unerupted teeth in $5.8 \%$ of their patients, resulting in an IORN rate of 5.5\% [7]. Schuurhuis et al. summarized 2011 the data of 185 patients and found oral infectious foci in $75 \%$, a periodontal pocket depth of more than $6 \mathrm{~mm}$ in $23 \%$, severe caries in $4 \%$, impacted teeth in $4 \%$, and residual root tips in $3 \%$. Tooth extractions had to be performed in $30 \%$ of the patients, a mean of 7.7 teeth had to be removed. Periodontal treatment was performed in 6\%. IORN was diagnosed in $11 \%$ [8]. Further literature data on this topic have been summarized in Table 6 [7,9-12]. In general, tumor patients frequently show a noncompliance in routine dental care and daily oral hygiene. Tumor diagnosis did not change the patients' habits: Lockhart and al. [12] stated that 97\% of their patients needed dental care before radiotherapy, but only $81 \%$ underwent the indicated treatment.

We can summarize from this data that patients with head and neck neoplasms show a far more unfavorable

Table 6 Dental status and rehabilitation procedures in the literature for IORN in the upper and lower jaw

\begin{tabular}{|c|c|c|c|c|}
\hline Author group & $\begin{array}{l}\text { Year of } \\
\text { publication }\end{array}$ & Dental status & $\begin{array}{l}\text { Rehabilitation } \\
\text { procedures }\end{array}$ & Remarks \\
\hline $\begin{array}{l}\text { Frydrych et al. } \\
(\mathrm{n}=82)[9]\end{array}$ & 2011 & No information & No information & $\begin{array}{l}\text { Average (median) date of last dental visit: } \\
66.76 \text { months ( } 18 \text { months) before radiotherapy }\end{array}$ \\
\hline \multirow{4}{*}{$\begin{array}{l}\text { Guggenheimer et al. } \\
(n=947)[10]\end{array}$} & \multirow[t]{4}{*}{1994} & Edentulous: 59\% & \multirow[t]{4}{*}{ No information } & \\
\hline & & Partially edentulous: 9\% & & \\
\hline & & $\begin{array}{l}\text { Poor dentition with no } \\
\text { replacement: } 14 \%\end{array}$ & & \\
\hline & & Intact dentition: 18\% & & \\
\hline \multirow{3}{*}{$\begin{array}{l}\text { Maier et al. } \\
(n=100)[11]\end{array}$} & \multirow[t]{3}{*}{1993} & Tumour vs. control patients: & \multirow[t]{3}{*}{ No information } & Tumour vs. control patients \\
\hline & & larlar > 3 mm: 40.91 vs. $21.98 \%$ & & Never tooth brushing 44.9 vs. $23.5 \%$ \\
\hline & & Decayed teeth $>50 \%$ : 27.2 vs. $3.9 \%$ & & Dental visit more than once a year: $6 \%$ vs. $43.5 \%$ \\
\hline \multirow[t]{3}{*}{$\begin{array}{l}\text { Lockhart et al. } \\
(\mathrm{n}=131)[12]\end{array}$} & \multirow[t]{3}{*}{1994} & Alveolar bone loss: $66 \%$ & $\begin{array}{l}\text { Needing dental care: } \\
97 \%\end{array}$ & Noncompliant with routine dental care: $76 \%$ \\
\hline & & Clinical caries: $71 \%$ & \multirow{2}{*}{$\begin{array}{l}\text { Did not seek the } \\
\text { indicated treatment: } \\
81 \%\end{array}$} & \multirow[t]{2}{*}{ Noncompliant with routine oral hygiene: $65 \%$} \\
\hline & & Failing restorations: 91\% & & \\
\hline \multirow{4}{*}{$\begin{array}{l}\text { Jham et al. } \\
(n=207)[7]\end{array}$} & \multirow[t]{4}{*}{2008} & Periodontal disease: $41 \%$ & \multirow[t]{4}{*}{ No information } & \\
\hline & & Residual root: $21.2 \%$ & & \\
\hline & & Caries $12 \%$ & & \\
\hline & & Unerupted tooth: 5.8\% & & \\
\hline
\end{tabular}


Table 7 Incidence of IORN of the upper and lower jaw in the literature

\begin{tabular}{|c|c|c|c|}
\hline Author group & Year of publication & Incidence & Remarks \\
\hline \multirow[t]{4}{*}{ Ben-David et al. [13] $(n=176)$} & 2007 & 0 & Multiple tumour localizations \\
\hline & & & Primary treatment (no surgery) \\
\hline & & & IMRT \\
\hline & & & 108/176 radiochemotherapy \\
\hline Berger et al. [14] & 2010 & $1-5 \%$ & Literature survey \\
\hline Crombie et al. [15] $(n=54)$ & 2012 & $36 \%$ & 53/54 radiochemotherapy \\
\hline \multirow[t]{2}{*}{ Gomez et al. [16] $(n=168)$} & 2011 & $1.2 \%$ & Multiple tumour localizations \\
\hline & & & IMRT \\
\hline Gomez et al. [29] $(n=35)$ & 2009 & $5 \%$ & IMRT \\
\hline Jerecek-Fosså et al. [17] & 2002 & $0.4-56 \%$ & Literature survey \\
\hline Jham et al. [7] $(n=207)$ & 2008 & $5.5 \%$ & Head and neck cancer \\
\hline Katsura et al. [18] $(n=39)$ & 2008 & $15 \%$ & \\
\hline Lee et al. [19] $(n=189)$ & 2008 & $6.6 \%$ & Oral cavity and oropharynx \\
\hline Monnier et al. [20] ( $n=73)$ & 2011 & $40 \%$ & Oral cavity and oropharynx \\
\hline Oh et al. [21] $(n=81)$ & 2004 & $4.9 \%$ & \\
\hline Reuther et al. [5] $(n=830)$ & 2003 & $8.2 \%$ & Oral cavity and oropharynx \\
\hline Stenson et al. [22] $(n=27)$ & 2010 & $18.4 \%$ & Surgery, adjuvant radiochemotherapy \\
\hline Storey et al. [23] $(n=83)$ & 2001 & $6 \%$ & Malignant submandibular tumours \\
\hline \multirow[t]{3}{*}{ Studer et al. [24] $(n=304)$} & 2011 & Grade 2 EORTC: $1.6 \%$ & Oral cavity and oropharynx \\
\hline & & & Conventional dental care vs. risk-adapted dental care \\
\hline & & & IMRT \\
\hline Thiel [25] & 1989 & $4-35 \%$ & Literature survey \\
\hline Thorn et al. [26] $(n=80)$ & 2000 & $74 \% / 3$ years & Multiple tumour localizations \\
\hline Tsai et al. [27] $(n=402)$ & 2013 & $7.5 \%$ & Oropharyngeal cancer, median time to IORN 8 months \\
\hline Turner et al. [28] $(n=333)$ & 1996 & $5.9 \%$ & \\
\hline
\end{tabular}

denta health status than a healthy population does; our findings are well within the range of the data taken from the literature seen above.

\section{Frequency of IORN}

The incidence of IORN varies widely $(0-74 \%)$ as depicted in Table 7 whereas the majority of data are in a range of $5-10 \%$. However, the comparison of these values to each other and to our results is very difficult due to a different definition or staging of IORN, different tumor localizations, therapy schedules, radiation techniques and dosages. Our results fit well within the range of data taken from the literature [5,7,13-29]. One of the data sets in the literature most comparable to our dataset has been published by Lee et al. [19] who experienced comparable IORN frequencies in a collective of patients having been operated on mainly.

\section{Risk factors for the development of IORN}

Numerous prognostic factors for the development of IORN have been tested and published. A selection of these is summarized in Table $8[3,4,14,17,18,20,27,28,30-39]$. The localization of the primary tumour in the oral cavity with its microbial colonization and the abundant involvement of the mandibular bone with its unique blood supply probably promotes IORN. Unfavourable dental status, periodontal disease and irritation of the gingiva by pressure sore triggered by dental prosthesis are important as well as dental extractions before and especially after radiotherapy and do also promote an infestation of the upper jaw.

Radiation dose should not exceed 60 - 66Gy to the mandibular bone whenever possible, the target volume within the bone should be limited. Some authors regard hyperfractionation a risk factor for IORN whereas Intensity modulated radiotherapy (IMRT) has been found advantageous compared to conventional 3D-planned radiotherapy. Additional factors may be chemotherapy, higher body mass index and the use of steroids.

We found odontogenic cysts and carious teeth to be significant prognostic factors univariately and odontogenic cysts multivariately. This rather unusual finding may result from the low number of patients in 
Table 8 Risk factors for IORN of the upper and lower jaw in the literature

\begin{tabular}{|c|c|c|c|}
\hline Author group & Year of publication & Risk factor(s) & Remarks \\
\hline Ahmed et al. [30] & 2009 & $\begin{array}{l}\text { Intensity modulated radiotherapy (IMRT) advantageous compared } \\
\text { to conventional radiotherapy }\end{array}$ & \\
\hline Berger et al. [14] & 2010 & Total dose >66Gy & Literature survey \\
\hline \multirow[t]{3}{*}{ Bhide et al. [31] } & \multirow[t]{3}{*}{2012} & Total dose > 60Gy & \multirow[t]{10}{*}{ Literature survey } \\
\hline & & $\begin{array}{l}\text { Volume of mandible within the treatment field. Trauma related } \\
\text { ORN after lower doses }\end{array}$ & \\
\hline & & IMRT & \\
\hline \multirow[t]{7}{*}{ Chopra et al. [32] } & \multirow[t]{7}{*}{2011} & White ethnicity & \\
\hline & & Secondary infection & \\
\hline & & Advanced age & \\
\hline & & Stage IV & \\
\hline & & Total dose & \\
\hline & & Post-RT dental extractions & \\
\hline & & Lack of pre-RT dental extractions & \\
\hline \multirow[t]{3}{*}{ Goldwasser et al. [33] } & \multirow[t]{3}{*}{2007} & Higher body mass index & \multirow[t]{3}{*}{ Multivariate analysis } \\
\hline & & Use of steroids & \\
\hline & & Radiation dose >66Gy & \\
\hline \multirow[t]{8}{*}{ Jerecek-Fosså et al. [17] } & \multirow[t]{8}{*}{2002} & Total dose & \multirow{8}{*}{$\begin{array}{l}\text { Literature survey, only part of } \\
\text { the factions mentioned in the } \\
\text { paper cited here }\end{array}$} \\
\hline & & Brachytherapy dose & \\
\hline & & Dose per fraction & \\
\hline & & Interval between fractions & \\
\hline & & $\begin{array}{l}\text { Volume of the horizontal ramus of the mandible irradiated with a } \\
\text { high dose }\end{array}$ & \\
\hline & & Dental status & \\
\hline & & Bad oral hygiene & \\
\hline & & Dental extractions after radiotherapy & \\
\hline \multirow[t]{5}{*}{ Katsura et al. [18] } & \multirow[t]{5}{*}{2008} & Oral health status after radiotherapy & \\
\hline & & Periodontal pocket depth & \\
\hline & & Dental plaque & \\
\hline & & Alveolar bone loss level & \\
\hline & & Radiographic periodontal status & \\
\hline \multirow[t]{2}{*}{ Lee et al. [19] } & \multirow[t]{2}{*}{2009} & Univariate: Mandibular surgery & $\begin{array}{l}\text { Multivariate analysis: } \\
\text { Mandibular surgery }\end{array}$ \\
\hline & & Co-60 & BED >106.2Gy \\
\hline \multirow[t]{2}{*}{ Lozza et al. [35] } & \multirow[t]{2}{*}{1997} & Dose rate & \multirow[t]{2}{*}{ Brachytherapy exclusively } \\
\hline & & Reference volume & \\
\hline \multirow[t]{8}{*}{ Curi et al. [3] } & \multirow[t]{8}{*}{1997} & Oral cancer & \\
\hline & & Invasion of bone & \\
\hline & & Tumour surgery & \\
\hline & & Total radiation dose & \\
\hline & & Dose rate/day & \\
\hline & & Mode of radiation delivery & \\
\hline & & Dental status & \\
\hline & & Time from radiation therapy until the onset of ORN & \\
\hline
\end{tabular}


Table 8 Risk factors for IORN of the upper and lower jaw in the literature (Continued)

\begin{tabular}{|c|c|c|c|}
\hline \multirow[t]{4}{*}{ Monnier et al. [20] } & \multirow[t]{4}{*}{2011} & Oral cavity tumours & \multirow{4}{*}{$\begin{array}{l}\text { Multivariate analysis: bone } \\
\text { surgery }\end{array}$} \\
\hline & & Bone invasion & \\
\hline & & Surgery prior to radiotherapy & \\
\hline & & Bone surgery & \\
\hline \multirow[t]{2}{*}{ Nabil et al. [36] } & \multirow[t]{2}{*}{2012} & Hyperfractionation & \multirow[t]{6}{*}{ Literature survey } \\
\hline & & Reduced risk after accelerated radiotherapy with reduced dose & \\
\hline \multirow[t]{4}{*}{ Reuther et al. [4] } & \multirow[t]{4}{*}{2003} & Advanced tumours & \\
\hline & & Segmental resection of the mandible & \\
\hline & & Tooth extractions (pre/post RT) & \\
\hline & & Pre-surgical radiotherapy worse than post-surgical radiotherapy & \\
\hline Støre and Boysen [37] & 2000 & $\begin{array}{l}\text { Tumour localization in tongue and floor of mouth } \\
\text { trauma }\end{array}$ & \\
\hline \multirow[t]{7}{*}{ Thiel et al. [38] } & \multirow[t]{7}{*}{1989} & Caries & \\
\hline & & Periondontosis & \\
\hline & & Periapical pathology & \\
\hline & & Injury & \\
\hline & & Irritation by prostheses & \\
\hline & & Dental extractions before and after radiotherapy & \\
\hline & & Bone surgery because of remaining or recurrent tumours & \\
\hline \multirow[t]{4}{*}{ Thorn et al. [39] } & \multirow[t]{4}{*}{2000} & Removal of teeth & \\
\hline & & Surgery & \\
\hline & & Injury from prosthesis & \\
\hline & & Spontaneous breakdowns & \\
\hline \multirow[t]{5}{*}{ Tsai et al. [27] } & \multirow[t]{5}{*}{2013} & Total dose & \\
\hline & & Dental status & \\
\hline & & Smokers & \\
\hline & & Alcohol & \\
\hline & & Larger tumours & \\
\hline \multirow[t]{7}{*}{ Turner et al. [24] } & \multirow[t]{7}{*}{1996} & Bone involvement & \\
\hline & & Synchronous Methotrexate & \\
\hline & & Scattered dose from elective & \\
\hline & & neck treatment & \\
\hline & & Increasing dose & \\
\hline & & Increasing target volumes for doses $<55 \mathrm{~Gy}$ & \\
\hline & & Dental extractions & \\
\hline
\end{tabular}

the IORN group and the fact that for some variables the data were incomplete.

Apart from this analysis, hyperfractionation seemed to have a protective effect whereas this could not be examined further due to the small number of events. In our ancient publication on this topic [2] (a very detailed comparison is currently under preparation) we experienced a very high frequency of IORN after hyperfractionated radiotherapy which may have been caused by to high total doses on the one hand and a too short interfraction interval (time interval between the two daily fractions) on the other hand.
Both factors have been taken into account here, consequently the results were improved markedly.

An important paper has been published by Tsai et al. in 2013 [27]. They reviewed the records of patients with small oropharyngeal cancers having undergone radiotherapy or radiochemotherapy. The overall prevalence of IORN was 7.5\%, higher doses, use of nicotine and alcohol, dental status as well as more advanced tumors were found significant risk factors for the development of IORT. In contrast to this paper our patients' primary situation seems more unfavorable: we only examined 
patients with oral cancer where the whole mandible was within the 100\%-isodose, thus we applied even higher doses to a large amount of bone. Furthermore, older techniques have been used; unfortunately, no information about fractionation has been given. Consequently, a higher prevalence of IORN here seems to be explainable.

\section{Conclusions}

In our patient collective the dental status was very poor, extensive dental and oral and maxillofacial restoration procedures had to be performed. This meticulous dental care resulted in an incidence of IORN of $12 \%$, all of them had undergone conventionally fractionated radiotherapy. It was very interesting to see that in the hyperfractionated group no IORN occurred at all. Significant prognostic factors could not be found. Our data fit well to those taken from the literature.

\section{Abbreviations}

ORN: Osteoradionecrosis; IORN: Infected osteoradionecrosis; RT: Radiotherapy; RCT: Radiochemotherapy; WHO: World Health Organization; EORTC: European Organization for research and treatment of cancer; RTOG: Radiation therapy oncology group; DMS: Forth German trial of oral health; ICRU: International commission on radiation units.

\section{Competing interests}

The authors declare that they have no competing interests.

\section{Authors' contributions \\ MN supervised data acquisition and evaluation and wrote the manuscript. JF was responsible for the patients' radiotherapy procedures and revised the manuscript. KM collected the data and re-examined the x-rays. The data presented here are a part of Mrs. M's thesis. HH and WJS revised the manuscript in the fields of dentistry and oral and maxillofacial surgery. CR supervised the patients' radiotherapy and approved the manuscript. All authors read and approved the final manuscript.}

\section{Acknowledgements}

The authors wish to acknowledge Dr. rer. nat. Norbert Licht, Head Physicist and his colleagues for computing the radiotherapy plans and many fruitful discussions. Furthermore we wish to thank the doctors, nurses and secretaries in the two departments involved here who performed the patients' treatment and furthermore were of important help in searching for the files and contacting the patients. Furthermore, PD Dr. Stefan Gräber, Dept. of Medical Biometry, Epidemiology and Medical Informatics of the Saarland University Medical School is acknowledged for statistical advice.

\section{Author details}

'Department of Radiotherapy and Radiooncology, Saarland University Medical Center, Kirrberger Str. 1, D-66421 Homburg, Germany. ${ }^{2}$ Dental Practice, Duisburg, Germany. '3 Department of Oral and Maxillofacial Surgery, Saarland University Medical Center, Kirrberger Str. 1, D-66421 Homburg, Germany.

Received: 18 April 2013 Accepted: 17 September 2013 Published: 2 October 2013

\section{References}

1. Kim JH, Chu FC, Pope RA, Woodard HQ, Bragg DB, Shidnia H: Proceedings: Time dose factors in radiation induced osteitis. Am J Roentgenol Radium Ther Nucl Med 1974, 120:684-690.

2. Niewald M, Barbie O, Schnabel K, Engel M, Schedler M, Nieder C, Berberich W: Risk factors and dose-effect relationship for osteoradionecrosis after hyperfractionated and conventionally fractionated radiotherapy for oral cancer. Br J Radiol 1996, 69:847-851.
3. Curi MM, Dib LL: Osteoradionecrosis of the jaws: a retrospective study of the background factors and treatment in 104 cases. J Oral Maxillofac Surg 1997, 55:540-544. discussion 545-546.

4. Reuther T, Schuster T, Mende U, Kubler A: Osteoradionecrosis of the jaws as a side effect of radiotherapy of head and neck tumour patients-a report of a thirty year retrospective review. Int J Oral Maxillofac Surg 2003, 32:289-295.

5. Schwartz HC, Kagan AR: Osteoradionecrosis of the mandible: scientific basis for clinical staging. Am J Clin Oncol 2002, 25:168-171.

6. Kern R, Krämer J, Michaelis W: Vierte Deutsch Mundgesundheitsstudie des Instituts der Deutschen Zahnärzte. Berlin: Bundeszahnärztekammer; 2006.

7. Jham BC, Reis PM, Miranda EL, Lopes RC, Carvalho AL, Scheper MA, Freire AR: Oral health status of 207 head and neck cancer patients before, during and after radiotherapy. Clin Oral Investig 2008, 12:19-24.

8. Schuurhuis JM, Stokman MA, Roodenburg JL, Reintsema H, Langendijk JA, Vissink A, Spijkervet FK: Efficacy of routine pre-radiation dental screening and dental follow-up in head and neck oncology patients on intermediate and late radiation effects. A retrospective evaluation. Radiother Oncol 2011, 101:403-409.

9. Frydrych AM, Slack-Smith LM: Dental attendance of oral and oropharyngeal cancer patients in a public hospital in Western Australia. Aust Dent J 2011, 56:278-283.

10. Guggenheimer J, Hoffman RD: The importance of screening edentulous patients for oral cancer. J Prosthet Dent 1994, 72:141-143.

11. Maier H, Zoller J, Herrmann A, Kreiss M, Heller WD: Dental status and oral hygiene in patients with head and neck cancer. Otolaryngol Head Neck Surg 1993, 108:655-661.

12. Lockhart PB, Clark J: Pretherapy dental status of patients with malignant conditions of the head and neck. Oral Surg Oral Med Oral Pathol 1994, 77:236-241.

13. Ben-David MA, Diamante M, Radawski JD, Vineberg KA, Stroup C, MurdochKinch CA, Zwetchkenbaum SR, Eisbruch A: Lack of osteoradionecrosis of the mandible after intensity-modulated radiotherapy for head and neck cancer: likely contributions of both dental care and improved dose distributions. Int J Radiat Oncol Biol Phys 2007, 68:396-402.

14. Berger A, Bensadoun RJ: Normal tissue tolerance to external beam radiation therapy: the mandible. Cancer Radiother 2010, 14:295-300.

15. Crombie AK, Farah C, Tripcony L, Dickie G, Batstone MD: Primary chemoradiotherapy for oral cavity squamous cell carcinoma. Oral Oncol 2012, 48:1014-1018.

16. Gomez DR, Estilo CL, Wolden SL, Zelefsky MJ, Kraus DH, Wong RJ, Shaha AR, Shah JP, Mechalakos JG, Lee NY: Correlation of osteoradionecrosis and dental events with dosimetric parameters in intensity-modulated radiation therapy for head-and-neck cancer. Int J Radiat Oncol Biol Phys 2011, 81:e207-e213.

17. Jereczek-Fossa BA, Orecchia R: Radiotherapy-induced mandibular bone complications. Cancer Treat Rev 2002, 28:65-74.

18. Katsura K, Sasai K, Sato K, Saito M, Hoshina H, Hayashi T: Relationship between oral health status and development of osteoradionecrosis of the mandible: a retrospective longitudinal study. Oral Surg Oral Med Oral Pathol Oral Radiol Endod 2008, 105:731-738.

19. Lee JA, Huh SJ, Oh D, Bae DS: Osteoradionecrosis after three-dimensional conformal radiotherapy for recurrent cervical cancer presenting as a progressive osteolytic lesion. Ann Nucl Med 2008, 22:139-141.

20. Monnier Y, Broome M, Betz M, Bouferrache K, Ozsahin M, Jaques B: Mandibular osteoradionecrosis in squamous cell carcinoma of the oral cavity and oropharynx: incidence and risk factors. Otolaryngol Head Neck surg 2011, 144:726-732.

21. Oh HK, Chambers MS, Garden AS, Wong PF, Martin JW: Risk of osteoradionecrosis after extraction of impacted third molars in irradiated head and neck cancer patients. J Oral Maxillofac Surg 2004, 62:139-144.

22. Stenson KM, Kunnavakkam R, Cohen EE, Portugal LD, Blair E, Haraf DJ, Salama J, Vokes EE: Chemoradiation for patients with advanced oral cavity cancer. Laryngoscope 2010, 120:93-99.

23. Storey MR, Garden AS, Morrison WH, Eicher SA, Schechter NR, Ang KK: Postoperative radiotherapy for malignant tumors of the submandibular gland. Int J Radiat Oncol Biol Phys 2001, 51:952-958.

24. Studer G, Glanzmann C, Studer SP, Gratz KW, Bredell M, Locher M, Lutolf UM, Zwahlen RA: Risk-adapted dental care prior to intensity- 
modulated radiotherapy (IMRT). Schweiz Monatsschr Zahnmed 2011, 121:216-229

25. Thiel HJ: Osteoradionecrosis. I. Etiology, pathogenesis, clinical aspects and risk factors. Radiobiol Radiother 1989, 30:397-413.

26. Thorn JJ, Kallehave F, Westergaard P, Hansen EH, Gottrup F: The effect of hyperbaric oxygen on irradiated oral tissues: transmucosal oxygen tension measurements. J Oral Maxillofac Surg 1997, 55:1103-1107.

27. Tsai CJ, Hofstede TM, Sturgis EM, Garden AS, Lindberg ME, Wei Q, Tucker SL, Dong $\mathrm{L}$ : Osteoradionecrosis and radiation dose to the mandible in patients with oropharyngeal cancer. Int J Radiat Oncol Biol Phys 2013, 85:415-420.

28. Turner SL, Slevin NJ, Gupta NK, Swindell R: Radical external beam radiotherapy for 333 squamous carcinomas of the oral cavity-evaluation of late morbidity and a watch policy for the clinically negative neck. Radiother Oncol 1996, 41:21-29.

29. Gomez DR, Zhung JE, Gomez J, Chan K, Wu AJ, Wolden SL, Pfister DG Shaha A, Shah JP, Kraus DH, et al: Intensity-modulated radiotherapy in postoperative treatment of oral cavity cancers. Int I Radiat Oncol Biol Phys 2009, 73:1096-1103

30. Ahmed M, Hansen VN, Harrington KJ, Nutting CM: Reducing the risk of xerostomia and mandibular osteoradionecrosis: the potential benefits of intensity modulated radiotherapy in advanced oral cavity carcinoma. Med Dosim 2009, 34:217-224

31. Bhide SA, Ahmed M, Newbold K, Harrington KJ, Nutting CM: The role of intensity modulated radiotherapy in advanced oral cavity carcinoma. J Cancer Res Ther 2012, 8(Suppl 1):S67-S71.

32. Chopra S, Kamdar D, Ugur OE, Chen G, Peshek B, Marunick M, Kim H, Lin $\mathrm{HS}$, Jacobs J: Factors predictive of severity of osteoradionecrosis of the mandible. Head Neck 2011, 33:1600-1605.

33. Goldwasser BA, Chuang S-K, Kabal LB, August M: Risk factor assessment for the development of osteoradionecrosis. J Oral Maxillofac Surg 2007, 65:2311-2316

34. Lee IJ, Koom WS, Lee CG, Kim YB, Yoo SW, Keum KC, Kim GE, Choi EC, Cha $\mathrm{H}$ : Risk factors and dose-effect relationship for mandibular osteoradionecrosis in oral and oropharyngeal cancer patients. Int I Radiat Oncol Biol Phys 2009, 75:1084-1091.

35. Lozza L, Cerrotta A, Gardani G, De Marie M, Di Russo A, Kenda R, Tana S, Valvo F, Zucali R: Analysis of risk factors for mandibular bone radionecrosis after exclusive low dose-rate brachytherapy for oral cancer. Radiother Oncol 1997, 44:143-147.

36. Nabil S, Samman N: Risk factors for osteoradionecrosis after head and neck radiation: a systematic review. Oral Surg Oral Med Oral Pathol Oral Radiol 2012, 113:54-69.

37. Store G, Boysen M: Mandibular osteoradionecrosis: clinical behaviour and diagnostic aspects. Clin Otolaryngol Allied Sci 2000, 25:378-384.

38. Thiel HJ: Osteoradionecrosis. II: Therapy and prevention. Radiobiol Radiother (Berl) 1989, 30:493-501.

39. Thorn JJ, Hansen HS, Specht L, Bastholt L: Osteoradionecrosis of the jaws: clinical characteristics and relation to the field of irradiation. J Oral Maxillofac Surg 2000, 58:1088-1093. discussion 1093-1085.

doi:10.1186/1748-717X-8-227

Cite this article as: Niewald et al.: Dental status, dental rehabilitation procedures, demographic and oncological data as potential risk factors for infected osteoradionecrosis of the lower jaw after radiotherapy for oral neoplasms: a retrospective evaluation. Radiation Oncology 2013 8:227.

\section{Submit your next manuscript to BioMed Central and take full advantage of:}

- Convenient online submission

- Thorough peer review

- No space constraints or color figure charges

- Immediate publication on acceptance

- Inclusion in PubMed, CAS, Scopus and Google Scholar

- Research which is freely available for redistribution
C Biomed Central 